University at Buffalo School of Law

Digital Commons @ University at Buffalo School of Law

$9-1-2020$

\title{
Presidential Selection: Historical, Institutional, and Democratic Perspectives
}

James A. Gardner

University at Buffalo School of Law, jgard@buffalo.edu

Follow this and additional works at: https://digitalcommons.law.buffalo.edu/book_sections

Part of the Constitutional Law Commons, and the Election Law Commons

\section{Recommended Citation}

Gardner, James A., "Presidential Selection: Historical, Institutional, and Democratic Perspectives" (2020). Contributions to Books. 395.

https://digitalcommons.law.buffalo.edu/book_sections/395

This material has been published in The Best Candidate: Presidential Nomination in Polarized Times edited by Eugene Mazo \& Michael Dimino. This version is free to view and download for personal use only. Not for redistribution, re-sale or use in derivative works. (c) Eugene D. Mazo and Michael R. Dimino 2020.

\section{IN COPYRIGHT}

This Book is brought to you for free and open access by the Faculty Scholarship at Digital Commons @ University at Buffalo School of Law. It has been accepted for inclusion in Contributions to Books by an authorized administrator of Digital Commons @ University at Buffalo School of Law. For more information, please contact lawscholar@buffalo.edu. 


\title{
Presidential Selection: Historical, Institutional, and Democratic Perspectives
}

\author{
James A. Gardner
}

It has been nearly two centuries since an American presidential election has evoked a crisis of confidence like that following the election of 2016. Not since the election of Andrew Jackson in 1828 has there been such a public display of anxiety concerning the methods by which we choose our chief executive. As in the contest of 1828 pitting the Democrat Jackson against his Federalist opponent John Quincy Adams, the presidential nominating process of 2016 produced a contest between a celebrity populist, widely seen as unqualified by experience or temperament, and a highly experienced and competent but deeply uninspiring political insider who had been anointed by establishment elites.

This anxiety ran deep in 2016: for the first time in the quarter-century during which such statistics have been recorded, neither major party candidate was viewed favorably by even half the electorate. ${ }^{1}$ The emerging verdict appears to be that our system for selecting presidential candidates failed catastrophically in 2016, an impression many regard as confirmed by the damage subsequently inflicted on the office of the presidency and on our democratic institutions by the winner, Donald Trump. In offering a wide variety of suggestions about how to improve the nominating process, the contributors to this volume endorse the proposition that our presidential selection procedures now operate poorly and are in need of repair, if not wholesale rethinking.

Meaningful criticism of the current process requires, however, that existing procedures be judged against some baseline of what constitutes a good candidate selection process, yielding good candidates who, one presumes,

James A. Gardner is Bridget and Thomas Black SUNY Distinguished Professor at the University at Buffalo Law School, State University of New York. He thanks Matt Steilen, Rick Su, Guyora Binder, and David McNamee for useful comments on a prior draft.

1 William G. Mayer, Was the Process to Blame? Why Hillary Clinton and Donald Trump Won Their Parties' Presidential Nominations, 93 N.Y.U. L. REV. 759 (2018). 
subsequently go on to become good presidents. If the current system works poorly, in other words, how should a good system of presidential nomination work? What kind of candidates should it produce, and how ought it to be structured so as to produce them? What kinds of improvements are needed, and how, if at all, can we obtain them? To address these questions, this chapter draws on three potential sources of guidance-history, institutional analysis, and democratic theory - and yields four broad conclusions.

First, an examination of the evolution of presidential nominating procedures since the founding reveals a steady historical trend of convergence in the identities of two critically important groups: the selectorate - the group authorized to choose officially recognized nominees ${ }^{2}$ - and the electorate - the group that chooses the ultimate officeholder from among the nominees. Second, this convergence is significant because the design of nominating procedures has important consequences for the kinds of candidates likely to emerge as nominees. Third, although democratic theory can help a polity clarify the values it wishes its democratic institutions to promote, a turn to democratic theory does not relieve a polity of the antecedent need to make hard choices about its goals and commitments, which must come before it makes its hard choices about institutional design. Finally, although law is useful and important in structuring a presidential nominating process, citizen ethos - the collective internalization of consensual democratic norms-may well be the single most important factor necessary to the consistent production of high-quality presidential candidates.

\section{EXPANSION OF THE PRESIDENTIAL SELECTORATE}

\section{A. The Founding Era (1788-1799)}

How to choose a president proved to be the most difficult issue the Philadelphia Convention addressed. After several false starts and lengthy debate, the Founders finally settled on a system that soon pleased no onethe Electoral College. Conceived as an intermediate body of wise and virtuous men who would stand between the people and the presidency, the members of the Electoral College were meant to exercise a kind of Burkean trusteeship in which they would base their selection of a president on "the information and discernment requisite to such complicated investigations" 3 - that is, on their

2 See, e.g., Reuven Y. Hazan \& Gideon Rahat, Democracy within Parties: Candidate Selection Methods and Their Political Consequences 33-54 (2010).

3 The Federalist, No. 68 (Hamilton). 
own sound, informed, and independent judgment. In so doing, the Electoral College would protect the people against their own human weakness and potentially poor judgment by assuring that excessively ambitious men, skilled in "low intrigue, and the little arts of popularity," would never attain the nation's highest office.

Interestingly, the Founders did not give much thought to the question of how qualified candidates for the presidency would come to the attention of the Electoral College. They did not provide for any system of nomination, nor did they grant the Electoral College any official authority to create one in the event that such a system should prove desirable. Instead, they seemed to assume that the nation's leading candidates for the presidency would simply be known, either personally or by reputation, ${ }^{5}$ to the members of the Electoral College - a reasonable assumption, perhaps, in a world in which the ruling elite in any state might have numbered in the dozens, or at most, in the hundreds. ${ }^{6}$

In this system, where nominations for the presidency were to be selfgenerated by the same body authorized to elect the president, the selectorate was precisely co-extensive with the electorate. Such an arrangement, the Framers believed, would be most conducive to the election of presidents with the desired characteristics, namely, "preeminen[ce] for ability and virtue."7 Certainly, the Founders would never have contemplated assigning the nominating function to political parties, an institution they considered detestably self-interested and factional, and indeed hoped would never appear on the American political landscape. ${ }^{8}$

\section{B. The First Party System (1800-1824)}

In less than two decades, of course, parties did appear on the scene, and they were quickly integrated into the presidential selection process. Parties of the Jeffersonian era were not like their modern counterparts; they did not conceive of themselves as representing a subset of the populace whose goal was to offer

4 Id.

5 James W. Ceaser, Presidential Selection: Theory and Development 66, 83 (1979).

6 For example, due to property qualifications, the number of people eligible to serve as governor of South Carolina under its 1778 constitution was probably twenty-five or fewer. James A. Gardner, Southern Character, Confederate Nationalism, and the Interpretation of State Constitutions: A Case Study in Constitutional Argument, 76 TEx. L. Rev. 1219, 1273 n.275 (1998).

7 The Federalist, No. 68 (Hamilton).

8 Richard Hofstadter, The Idea of a Party System: The Rise of Legitimate Opposition in the United States, 1780-1840, at 9 (1970). 
to the electorate a political vision or set of programmatic alternatives in a fair and equal competition for voter approval. Instead, parties of this era conceived of themselves as parties "of the whole people, not of any part or of any minority." The Jeffersonian Democratic-Republicans, in particular, thought of themselves as embodying the original, animating spirit of the revolutionary nation, a spirit that they believed required restoration following what they viewed as the subversion of the established constitutional order by the Federalists during the administration of John Adams. Self-organization into parties, for the Jeffersonians, was an unpleasant but temporary expedient that could be abandoned following successful restoration of the true revolutionary order. $^{10}$

To accomplish this task, the Jeffersonians deliberately exploited weaknesses in the design of the Electoral College to transform it into a vehicle of partisan mobilization. Their plan had two parts. First, they pre-selected their presidential candidate on partisan grounds, and through ground-level political activity promoted as candidates for the Electoral College individuals already committed to the party's candidate, an action that transformed members of the Electoral College into "instructed agents, not deliberative trustees." they de facto replaced the Electoral College as the instrument of candidate nomination with a newly devised, shadow organization, the congressional caucus. These caucuses consisted of informal meetings of members of Congress who shared party membership; at these caucuses, participants reached consensus on the identity of the party's candidate for the presidency. ${ }^{12}$ The caucus choice went on to win the presidency in every election from 1800 to $1816 .^{13}$

As a functional matter, the caucus system thus substituted the congressional caucus for the Electoral College as the nominating selectorate. As a result of this change, "[t]he ideological orthodoxy of the candidates ... became a decisive criterion for selection, while competence, virtue, and

9 Alfred De Grazia, Public and Republic 114 (reprint ed. 1985) (orig. ed. 1951).

10 Ceaser. supra note 5, at 91; Gerald Leonard, The Invention of Party Politics 22-25 (2002).

11 Ceaser, supra note 5, at 88.

12 Emmett H. Buell, Jr., Presidential Nominations of the Pre-Convention Era, in Enduring Controversies in Presidential Nominating Politics 35-38 (Emmett H. Buell, Jr. \& William G. Mayer eds., 2004); William G. Morgan, The Origin and Development of the Congressional Caucus, in Enduring Controversies, supra, at 60.

13 Stephen Gardbaum \& Richard H. Pildes, Populism and Institutional Design: Methods of Selecting Candidates for Chief Executive, 93 N.Y.U. L. REv. 647, 653 (2018). 
service to the state-the Founders' intended criteria-receded into the background."14

\section{The Second Party System (1828-1912)}

The emergence of the Democratic party and the successful election of its 1828 candidate for president, Andrew Jackson, permanently and dramatically changed the American system of presidential selection in two important ways. First, under the ideological leadership of Martin Van Buren, Jacksonian Democrats developed for the first time a justification for a system of permanent party competition. Such a system, they contended, would institutionalize popular sovereignty by ensuring, first, that the people would always have a ready alternative to the government in power; and second, that they could hold incumbents accountable by voting them out and voting into power the opposition party. Second, Jacksonian Democrats advanced a very different conception of the presidency: the president, they claimed, was the only official in the United States who represented, and was accountable to, the entirety of the populace. To ensure presidential responsiveness to the appropriate constituency, the process of selecting presidential candidates had to be committed to a "mass" party of nationwide scale ${ }^{15}$ whose members possessed a strong voice in the nominating process.

Jacksonian Democrats made good on these commitments by transferring the power to nominate from the congressional caucus to a national party convention. ${ }^{16}$ In this system, each party nominated its candidate at a national convention whose members were party delegates chosen principally by state and local party organizations to represent their membership. During the nineteenth century, and well into the twentieth, the actual selection of convention delegates was typically made directly by state and local party leaders, who consequently exercised a great deal of control over the course of the convention and the ultimate nomination. ${ }^{17}$ The selectorate, in this system, thus comprised convention delegates hand-picked by local party bosses.

14 Ceaser, supra note 5, at 96.

15 John Aldrich, Why Parties?: The Origin and Transformation of Political Parties in America 97-98 (1995).

16 Emmett H. Buell, Jr., The National Nominating Convention, in Enduring Controversies, supra note 12 , at 79 .

17 Gardbaum \& Pildes, supra note 13, at 654. 


\section{The Progressive Era (1912-1972)}

The Progressive movement arose in the 1880 s, reaching the height of its influence in the early twentieth century. In their political views, Progressives echoed the founding-era distaste for political parties, but on different grounds: they viewed parties as captives of local machine bosses and corrupted by corporate interests for the benefit of the wealthy. As a result, on the Progressive view, parties had collaborated in bending government policies away from their true purpose-service to the common good-and toward a clientelistic system of local plunder of public assets. At the same time, Progressives saw the presidency as requiring enormous power in the modern world, and indeed as the one organ of government most capable of operating effectively in a dangerous world that often required swift and energetic national action, and in a manner genuinely responsive to mass public opinion.

Progressives implemented these views by leading a successful movement to require parties to nominate candidates through the use of direct primary elections. First introduced in 1899, when the Minnesota legislature enacted direct primaries for Minneapolis local elections, ${ }^{18}$ the use of primary elections spread quickly: by 1916 over half the states utilized some form of primary, and by $195^{8}$ primary elections were nearly universally available, ${ }^{19}$ though not always mandatory.

The movement toward primary elections continued a trend of expanding the nominating selectorate. From the members of the Electoral College, to the members of a congressional caucus, to delegates to a nationwide party convention, the presidential selectorate now increasingly included the rank and file membership of national political parties.

\section{E. Consolidation of the Mass Selectorate: The 1970 Reforms and Beyond}

By the mid-twentieth century, although most states offered the option of nomination by direct primary, parties were not necessarily required to select convention delegates according to the results of primary elections. Instead, the route to a party's presidential nomination typically lay through a mixed system in which candidates still had to seek privately the personal support of party

Robert G. Boatwright, Congressional Primary Elections 27 (2014). There is some disagreement about where and when the first primary was introduced. Masket, for example, places it in Wisconsin in 1904. Seth Masket, The Inevitable Party: Why Attempts to Kill the Party System Fail and How They Weaken Democracy 127 (2016). 
leaders, but could sometimes help their case by demonstrating their ability to win votes in advisory primary elections. ${ }^{20}$

This system was replaced, almost at a stroke, following the divisive 1968 Democratic convention in Chicago. There, while anti-Vietnam War protests were violently suppressed by the local political boss, Chicago Mayor Richard Daley, the convention proceeded to nominate the establishment, pro-war candidate, Vice President Hubert Humphrey, passing over a highly popular, anti-war candidate, Senator Eugene McCarthy. In response to the subsequent outcry from many quarters within the party - and the party's crushing defeat at the hands of Richard Nixon - the Democratic Party created the McGovernFraser Commission to recommend changes to the party's presidential selection procedure for the 1972 election. The Commission's principal charge was to recommend ways to improve representation at the convention of previously excluded groups, including women, minorities, and young people. ${ }^{21}$

The Commission responded with recommendations to open up the process by decreasing the proportion of convention delegates chosen directly by party leaders, requiring transparency in the selection of delegates, and imposing quotas that would increase the diversity of convention delegations. The Party adopted these recommendations, leaving the mode of compliance to state party organizations. In an unforeseen development, state parties - joined in many cases by state legislatures through the exercise of their Article II power to direct the manner of appointment of presidential electors-complied by moving to an almost entirely plebiscitary system of delegate selection through direct primary elections. ${ }^{22}$ The Republican Party soon followed suit, in many cases under compulsion of state legislation. The changes were dramatic; as Gardbaum and Pildes explain, "[i]In 1968, the primaries had bound $36 \%$ of the delegates to each convention; just four years later, the primaries bound $58 \%$ of the Democratic delegates and $41 \%$ of the Republican ones, and by 1976 , twothirds of the Democrat delegates and more than half the Republican ones were bound." ${ }^{23}$ Thus, by the late-twentieth century, the presidential selectorate had come to comprise essentially the entirety of the national parties' rank and file membership. ${ }^{24}$

20 Gardbaum \& Pildes, supra note 13, at 655-56.

21 Ceaser, supra note 5, at 277-84.

22 Gardbaum \& Pildes, supra note 13, at 659 .

23 Id.

24 Political scientists disagree over the extent to which the move to direct primaries gave control over nominations to the party rank and file. According to one view, party elites continue to exercise a great degree of de facto control over the identity of nominees. See, e.g., Hans J. G. Hassell, Party Control of Party Primaries: Party Influence in Nominations for the U.S. Senate, 78 J. PoL. 75 (2015). Others, however, argue that the inclusiveness of nominating 
Even this, however, did not represent the conclusion of the trend of expansion of the selectorate. In subsequent decades, some states began to experiment with opening up their primary elections beyond party rank and file. In a "semi-closed" primary, used by some parties for at least some offices in more than a dozen states, independent voters-those who have chosen not to affiliate formally with any party - may nevertheless vote in primary elections. In such a primary, the selectorate thus consists of the party rank and file plus any independent voters who choose to participate. In an "open" primary, used by some parties for some offices in more than twenty states, voters may vote in any party's primary, even if they have registered as members of a different party. In these primaries, the selectorate is expanded to include not only the party's rank and file, but also members of opposing parties. And in a "nonpartisan" primary, used in California, Washington, and Louisiana, all voters, regardless of prior registration, may vote for any candidate of any party. The two candidates with the most votes then run against each other in the general election, regardless of their partisan affiliation. In this kind of primary, the selectorate consists in principle of the entire electorate. ${ }^{25}$

Moreover, in response to dissatisfaction within the Democratic party over the 2016 nomination process, especially from supporters of Senator Bernie Sanders, the chief competitor to Hillary Clinton, the national Democratic Party recently announced it will consider further empowering the rank and file by reducing the role of "superdelegates" at the national convention. These

processes has contributed to the creation of a candidate-centered politics in which alliances of candidates and their supporters effectively control the nominating process. See, e.g., HAZAN \& RAHAT, supra note 2 , at 148,151 . Some go even further, and argue that the polarity of party influence has reversed itself: instead of parties dictating the commitments of their nominees, it is candidates who now set the agenda to which their parties must then conform. See, e.g., Richard S. Katz, The Problem of Candidate Selection and Models of Party Democracy, 7 PARTY Pol. 277, 278 (2001); Austin Ranney, Candidate Selection, in Democracy at the Polls: A Comparative Study of Competitive National Elections 103 (David Butler et al. eds. 1981); Gerald C. Wright, Rules and the Ideological Character of Primary Electorates, in Reforming the Presidential Nomination Process 24 (Steven S. Smith \& Melanie J. Springer eds., 2009).

25 Another kind of primary, the so-called "blanket" primary, was invalidated by the Supreme Court in California Democratic Partyv. Jones, 530 U.S. 567 (2000). In a blanket primary, every voter may vote in the primary election for any candidate of any party. The candidate of each party with the most votes is declared that party's nominee for purposes of the general election. The difference between a blanket and non-partisan primary is that in a blanket primary, each party is forced to include in its selectorate all other voters, a feature that the Court viewed as an unconstitutional interference with the right of party members to choose with whom to associate. In a non-partisan primary, in contrast, parties are stripped of the right to nominate candidates onto the general election ballot, so no party, in the Court's view, is forced to associate with anyone against its will in choosing a nominee. 
delegates, who comprised about 15 percent of convention delegates in 2016, consist of party leaders and insiders whose presence at the convention had been thought to provide some ballast in the form of expertise and political experience.

In the march from semi-closed, to open, to non-partisan primary elections, the selectorate progressively becomes broader and broader to the point that it begins to converge with the electorate. History is thus in a sense circling back upon itself. During the founding era, the electorate and selectorate coincided, but both were extremely narrow in scope; in today's system, the electorate and selectorate also coincide, or nearly so, but both are broad-based, with the selectorate seemingly on a path soon to converge fully with the electorate. In the founding era version, nomination and election were the province of elites and party insiders, and non-elites and rank-and-file party members were excluded. Under today's system, nomination and election are the almost exclusive province of the mass electorate, and it is experienced, senior members of the party who lack a formal voice in the nominating process - a development that has been called, tellingly, the decline of "peer review."26

\section{INSTITUTIONAL EFFECTS: THE CONSEQUENCES OF NOMINATING PROCEDURES}

The United States is today a polity of more than 300 million, spread over thousands of miles of territory and, for purposes of presidential election, divided by law into 51 separate political communities. Because such an entity is incapable of spontaneously generating plausible candidates for national political office, some procedure for nominating candidates is therefore required. By nominating procedure, I mean simply mechanisms, established by law or by rules adopted by an officially recognized nominating entity, such as a political party, that distinguish candidates authorized to stand for office from those who are not. Moreover, because we want our presidents to be good ones, any procedure for generating presidential candidates should select them for the qualities we most wish our presidents to possess. The issue to which I now turn is the effect of nominating procedures on the characteristics possessed by candidates who successfully clear the hurdle of obtaining a nomination.

Variations in nominating procedures can in principle exert a triple screening effect on candidate characteristics. First, simply by establishing procedural

26 The term dates at least to the 1980s. See Elaine C. Kamarck, Returning Peer Review to the American Presidential Nomination Process, 93 N.Y.U. L. Rev. 709 (2018). 
requirements to obtain nomination, they can influence at the outset who might be tempted even to attempt a presidential run. Second, by manipulating the identity of the selectorate, nominating procedures tend to prescreen for the kinds of individuals who are most capable of making a successful appeal to the body doing the nominating. Third, by establishing the criteria that define the selectorate, and that distinguish one selectorate from another, nominating procedures can influence the substantive grounds along which the eventual candidates differentiate themselves.

\section{A. Self-Screening Effects}

Perhaps the most immediate impact of nominating procedures is their power to induce self-screening among potential candidates. The mere establishment of any set of nominating procedures will tend to attract candidates who are-or at least who think they are-more likely to succeed under the established procedures, and to deter those who are less likely to prosper under whatever procedures happen to prevail. For example, something as basic as a long primary season will tend to attract candidates who possess the physical robustness and mental and emotional stamina to traverse the entire process - characteristics in our day often spoken of, sometimes approvingly and sometimes not, as "fire in the belly." Potential candidates, even those well-qualified for the presidency on other grounds, are conversely likely to be deterred from attempting to run in a process that they suspect they will be either unlikely or unwilling to complete. Similarly, a nominating procedure that is expensive will tend to deter candidates who either do not possess or are unwilling to invest, substantial personal resources; or who are not well-positioned, either for lack of connections, pre-nomination public support, or native fund-raising ability, to raise the money necessary to make a presidential run.

\section{B. The Nature of Appeals to the Selectorate}

Selectorates may be defined in many different ways, for many different reasons, but one inevitable effect of defining a selectorate is to establish the characteristics of the group to which potential presidential candidates must appeal in order to secure nomination. ${ }^{27}$ As a result, nominating procedures will tend to screen in candidates who possess personal characteristics that allow them to appeal successfully to the relevant selectorate, and to screen out those who lack the characteristics or ability to make such appeals.

27 See Ceaser, supra note 5, at 18, 233; see also id. at 55, 62, 119 . 
This can have potentially significant consequences for the qualities possessed by candidates, because different qualities may be necessary to appeal successfully to different selectorates, depending on their composition. For example, if the selectorate is a congressional caucus, then the successful candidate must be able to appeal to sitting members of Congress, an elite group that is unusually well-informed about the qualities necessary for presidential success. Different characteristics and abilities, on the other hand, may be necessary to appeal successfully to a selectorate consisting of the entire party membership, the party activist base, local party bosses, rich donors, or other groups. Indeed, a common complaint about the current process of party nominations is that different qualities are necessary to appeal successfully to the party rank and file when seeking the nomination than are required to appeal to the electorate as a whole when running for the actual office. ${ }^{28}$

\section{Substantive Grounds of Nomination and Election}

Finally, and perhaps most importantly, nominating procedures establish the cleavages along which the choice of nominees will be made, thus influencing the issues that will be salient not only in the eventual choice of nominees, but in the general election. The mechanism-unintended but inevitable-works like this. The establishment of nominating procedures includes defining the selectorate. If the system divides the polity into multiple selectorates, each of which is authorized to put forward nominees - if, that is, the bodies that do the nominating comprise some subset of the body that does the electing - then some criterion will necessarily define the various selectorates, distinguishing them from one another. The criteria that distinguish one selectorate from another in turn will then influence (though they need not fully determine) the criteria by which competing selectorates choose their nominees. And this in turn will influence the qualities that distinguish the nominees from one another in the general election, thereby influencing the grounds on which they are chosen by the electorate.

This phenomenon may be easiest to see by analogy to a more familiar one: dividing the electorate into legislative districts. ${ }^{29}$ Tip O'Neill, Speaker of the

28 Richard Nixon reportedly offered the following advice to Bob Dole, the 1996 Republican candidate for President: "you have to run as far as you can to the right [during the primaries] because that's where $40 \%$ of the people who decide the nomination are. And to get elected you have to run as fast as you can back to the middle, because only about $4 \%$ of the nation's voters are on the extreme right wing." Jack Nelson, Letters from Nixon Shape Dole's Campaign Strategy, L.A. Times, May 7, 1995.

29 Here I draw on an argument made in James A. Gardner, How to Do Things with Boundaries: Redistricting and the Construction of Politics, 11 Election L.J. 399 (2012). 
U.S. House of Representatives from 1977 to 1987 , famously quipped that "all politics is local." $3^{\circ} \mathrm{O}$ 'Neill was accurate, but as political theorist Andrew Rehfeld subsequently observed, all politics is local only because we draw legislative districts territorially. If we drew districts based on occupation, Rehfeld argued, then "all politics would be "vocational." ${ }^{11}$ The important point is that in a contestatory political system, the contest often, even usually, will be won or lost along the cleavages that define the sorting of voters, ${ }^{32}$ and the identity of those issue cleavages can be managed - or manipulated - in the process of drawing the districts.

The same holds for the process by which we divide the nationwide presidential electorate into competing selectorates, which might usefully be conceived as a kind of electoral "districting." If, for example, we defined selectorates by gender, with men entitled to nominate one candidate and women another, issues related to gender would be much more likely than under the present system regularly to rise to prominence in the nomination process. If selectorates were designated by race, ethnicity, or language, then those issues would likely be highly salient in the nominating and electoral phases. If the selectorates corresponded to income groupingssay, for example, the rich got to nominate one candidate, the middle class another, and so on - then issues of economic class would likely predominate in the selection of nominees. The point, again, is that the criteria used to define the selectorates will influence the cleavages that divide the candidates at the nomination phase, and thus the nature of the issues that confront the electorate in the general election. Thus, how we nominate influences not just the personal characteristics of the candidates, but the grounds on which they are likely to compete first for nomination, and then for election.

As it happens, we have for more than two hundred years assigned the job of producing nominations to national political parties, organizations that generally tend to distinguish themselves - at least in theory - along a spectrum of political ideology. By defining the selectorate in ideological terms, our system thus tends to produce-and, one presumes, is intended to produce-nominees who are distinguished from one another mainly on the basis of their ideological and programmatic commitments, thus presenting the electorate with a choice lying

30 Thomas P. O’Neill, All Politics Is Local and Other Rules of the Game (1993).

31 Andrew Rehfeld, The Concept of Constituency: Political Representation, Democratic Legitimacy, and Institutional Design 8 (2005).

32 Thomas W. Pogge, Self-Constituting Constituencies to Enhance Freedom, Equality, and Participation in Democratic Procedures, 49 Theoria 26, 49 (2002); Lani Guinier, The Tyranny OF THE Majority 101 (1994). 
along that axis. Although from many perspectives it may be desirable to design a system that tends to force voters into choosing among candidates on ideological grounds, ideology is not the only criterion salient to presidential success. Section D below takes up the question of whether it is possible to define selectorates so as to generate candidates who distinguish themselves along other salient dimensions.

\section{Congruence of Selectorate and Electorate}

As discussed earlier, a strong historical trend in the evolution of presidential nominating procedures has produced a growing convergence between presidential selectorates and the presidential electorate, with the former slowly expanding toward the boundaries of the latter. In light of the analysis set out above, what is the likely effect of such convergence on the grounds upon which selectorates nominate and electorates subsequently elect?

When the selectorate and the electorate are congruent, the potential benefits of deliberate institutional design are nullified: the system fails to nudge the choice of candidates into any particular orientation, so the choice of nominees is no longer channeled along any particular set of criteria or along any cleavage upon which the electorate might reasonably be thought-or hoped - to divide. As a result, nominations can much more easily be made upon any ground, whether or not relevant to the qualities presidential nominees ought to possess. Control over the criteria of nomination - that is to say, the advantage associated with the power to set the agenda - is thus abandoned by the polity and in a sense delegated to the discretion of individual actors within the system.

Consider, for example, a small committee or board the rules of which permit nominations for officers to be made by any member, without restriction. In those circumstances, the grounds for nomination will be determined entirely by the discretion of individual members. Board members might nominate on the basis of competence or experience, but they might just as easily nominate on the basis of family ties, personal friendship, hope of personal gain, race, gender, or religion. Any constraints on the grounds of nomination, if they exist at all, will be supplied by informal norms of the group, and the constraining effect of those norms will depend entirely on the willingness of members to observe them. ${ }^{33}$

33 Hazan and Rahat argue that the inclusiveness of American parties' procedures for selecting legislative candidates is responsible for reducing party discipline within legislatures. Reuven 
It is worth recalling here that the Framers designed the Electoral College, in which the selectorate and electorate coincided, for the express purpose of impeding nomination on the basis of partisan ideology. Such a system, they hoped, would promote selection on the basis of national reputation, a reputation they felt could be earned only by individuals of great virtue and ability and little personal ambition, on the model of a Patriot King, Cincinnatus, or George Washington. ${ }^{34}$ But that reputation, they clearly believed, would be based on personal, non-partisan, non-ideological characteristics of the candidates. The Electoral College might have worked that way had the informal norms of the group remained stable. Those norms, however, changed radically when the Jeffersonians captured the process for electing members of the Electoral College and converted it into a system highly responsive to partisan considerations.

Moreover, even if the Framers were correct that congruence between the selectorate and electorate is likely to produce nominees with national reputations, the modern selectorate is very different from the Founding-era Electoral College, and changes in technology and political and social norms have drastically altered what it means to have a "national reputation," as well as the grounds upon which such a reputation can be made and the kinds of people who are capable of developing such a reputation. "Celebrity," in all its modern forms, simply did not exist in that era. In any case, both history and institutional logic demonstrate that congruence of the selectorate and the electorate creates institutional conditions in which the grounds of nomination are neither pressured by design incentives to lie along any particular axis of choice nor easily controlled by post-design regulatory measures.

\section{E. The Need for Intentional Design}

The foregoing historical and institutional analyses demonstrate, if nothing else, that a presidential nominating system might be built in many ways, and that details of design can exert some degree of influence-perhaps a considerable influence - on the criteria by which nominations are made, the qualities and characteristics of the nominees and ultimate officeholders, and even the grounds upon which the presidency is contested. There is thus no "natural" or even "best" way to structure a presidential nominating

Y. Hazan \& Gideon Rahat, Candidate Selection: Methods and Consequences, in Handbook of Party Politics 116-17 (Richard S. Katz \& William Crotty eds., 2006).

34 See Henry St. John Bolingbroke, The Idea of a Patriot King (1738); Ralph Ketchum, Presidents above Party: The First American Presidency, 1789-1829, at 89 (1984). 
procedure. On the contrary, the way such a system operates is highly contingent on its design, and it is therefore essential that a polity designing such a system for itself makes a clear and deliberate choice about the qualities it wants its candidates to possess, and then to build a nominating system adapted as well as possible to generating nominations of persons with those qualities.

But if, at the end of the day, we must make these kinds of hard choices, how should we do so? On what basis? Because nomination is an element of what has become a largely democratic process, one place to turn for assistance in making, or at least narrowing, the field of choices is democratic theory.

\section{DEMOCRATIC THEORY AND PRESIDENTIAL CHARACTERISTICS}

Over time, as we have seen, the process of presidential selection has become increasingly democratic, even plebiscitary. Since the founding, popular participation has increased dramatically during both the nomination phase, following the turn to direct primary elections, and during the election phase, following the conversion of the Electoral College into an institution that passes through, as far as its structure will allow, nationwide popular sentiment as expressed at the polls. To the extent that the process of presidential selection is democratic, then, democratic theory might offer some guidance about how best to structure it.

The guidance it offers, however, is limited. First, there are many competing theories of democracy, and each theory emphasizes different values and aspects of democratic practice. Consequently, democratic theory cannot definitively settle questions about democratic structure and practice, although it can help clarify the values among which polities must choose when designing democratic institutions. Second, most theories of democracy now in circulation do not readily generate concrete prescriptions for operationalizing their own commitments, so it is difficult to take guidance from them in designing appropriate implementing institutions. Third, even when democratic theories generate adequately specific prescriptions, those prescriptions often suffer from serious problems of infeasibility in actual implementation.

\section{A. Varieties of Democratic Theory}

"Democratic theory" is far from monolithic: many theories of democracy currently circulate. Below are a few of the most common. 
- Protective Democracy. From the time of the founding, one of the most common justifications for democratic forms of government is a set of theories that can be captured under the broad heading of "protective democracy." 35 Although the details sometimes vary, theories of protective democracy usually center on two core beliefs: that the ultimate purpose of government is to protect the rights and liberties of the citizenry; and that democracy is a form of government particularly well suited to accomplish that goal.

- Developmental Democracy. Generally associated with thinkers such as Mill $^{36}$ and, later, with participationists such as Pateman and Barber, ${ }^{37}$ theories of developmental democracy hold that the most important function of democracy is its capacity, by creating opportunities for popular participation in self-governance, to foster and maintain in the populace the skills of citizenship. These skills are critical because, as Mill wrote, "human beings are only secure from evil at the hands of others, in proportion as they have the power of being, and are, selfprotecting; and they only achieve a high degree of success in [that] struggle ..., in proportion as they are self-dependent, relying on what they themselves can do, ... rather than on what others can do for them." $3^{8}$

- Democratic Minimalism. Pioneered by the mid-twentieth-century political theorist Joseph Schumpeter, democratic minimalism holds that "the democratic method is that institutional arrangement for arriving at political decisions in which individuals acquire the power to decide by means of a competitive struggle for the people's vote." 39 On this view, the polity is fundamentally a passive observer of the political activities of elites, and its capacity to influence public affairs is limited to replacing one set of rulers with another.

- Aggregative Theories. More sophisticated versions of minimalism, aggregative or economic theories of democracy rest on the utilitarian premise that the good of society is achieved through the maximization of collective welfare. Democracy, in such theories, performs this function when parties and candidates offer competing programmatic commitments and voters then choose among the options by voting for the

David Held, Models of Democracy (1987).

John Stuart Mill, Considerations on Representative Government (1861).

Carole Pateman, Participation and Democratic Theory (1970); Benjamin Barber, Strong Democracy (1984).

MiLl, supra note 36 , ch. III.

Joseph Schumpeter, Capitalism, Socialism and Democracy 260 (1942). 
candidate whose policy commitments will provide them with the greatest benefits. ${ }^{40}$ Through the operation of forces similar to those prevailing in well-functioning markets, social utility is said to be maximized through the mechanical aggregation of the uncoordinated, self-interested decisions of voters.

- Deliberative Theories. The most recent entry into the field, deliberative theories of democracy reject the minimalist and aggregative premises that citizens have limited capacity to participate meaningfully in politics; and reject the contention that politics consists of the mere summing of individual utility preferences. Harkening back to earlier, thicker conceptions of democracy, deliberativists contend that citizens' preferences, and even their political self-understandings and identities, are formed in reasoned, self-conscious, and deliberative processes of political engagement; and that only viewpoints formed in this fashion are entitled to full consideration in the process by which a democratic society decides how best to govern itself. ${ }^{41}$

Each of these theories of democracy emphasizes different democratic values and aspects of democratic practice, and each thus offers distinct guidance as to the qualities that presidents and presidential candidates ought to possess. For example, under a theory of protective democracy, the most important quality a presidential candidate must possess would seem to be a substantive commitment to individual liberty. Aggregative theories, in contrast, seem to demand presidential candidates capable of balancing and adjusting competing voter preferences - a kind of talent for brokering..$^{2}$ Under deliberative theories, in contrast, the ideal presidential candidate would presumably be a skilled deliberator capable of leading the citizenry through a process of meaningful deliberation, who would respect, and exercise self-restraint in the face of, the outcomes of meaningful public deliberation.

For this reason, a turn to democratic theory cannot settle disputes over the qualities that presidential candidates ought to possess. It can, however, clarify the available choices and their consequences, and might therefore usefully assist a polity in recognizing those aspects of democracy that it most values and

$4^{\circ}$ Anthony Downs, An Economic Theory of Democracy (1957).

${ }^{41}$ See, e.g., Joshua Cohen, Deliberation and Democratic Legitimacy, in The Good Polity: Normative Analysis of the State (Alan Hamlin \& Philip Pettit eds. 1989); Jürgen Habermas, Between Facts and Norms: Contributions to a Discourse Theory of LaW and Democracy (William Rehg trans., 1996).

42 See Ceaser, supra note 5, at 158. 
wishes to advance in its democratic institutions and practices. This may not be an easy task. First, no general consensus exists as to the descriptive accuracy, normative attractiveness, or pragmatic feasibility of any of these theories, so there is no default preference that might be invoked in the face of disagreement. Second, the process of choosing among democratic theories is complicated by the fact that the various theories have acquired over time a distinct ideological valence, even a partisan one: present-day conservatives and libertarians tend to gravitate toward protective and aggregative theories of democracy, while liberals tend to prefer developmental and deliberative conceptions. Thus, any enterprise of attempting to choose, in a sober, constitutional mode, among foundational democratic theories runs the risk of activating the habitual partisan cleavages of ordinary politics.

The need for affirmative choice is all the more urgent, however, because not all of these characteristics are equally likely to reside in the same individual. Aggregative brokering, for example, is in a sense the precise opposite of deliberative consensus-building. Brokering among competing interests requires facilitating logrolling and compromise, a task undertaken most effectively by according unquestioned validity to the merits of participants' demands and underlying beliefs. Deliberative consensus-building, on the other hand, requires leading participants through a process of potentially transformative self-reflection and self-interrogation as a means to achieving consensus. Thus, a willingness to take guidance from democratic theory cannot relieve us of the necessity of making hard choices about normative ends. Instead, it tends simply to push those choices down a level, converting them from choices about the desired qualities of presidential candidates to choices among competing conceptions of democratic practice.

\section{B. Prescriptive Vagueness}

Even if societal agreement on a theory of democracy is feasible, theories of democracy often have surprisingly little to say about how best to operationalize their own normative commitments. This is in part a consequence of the historic focus of democratic theory since the Enlightenment: the legitimacy of governmental authority. The great problem to which the Enlightenment political project addressed itself was undermining divine providence as the basis of governmental — which is to say, monarchical - authority, and refounding it on popular consent. As a result, democratic theories are typically, at bottom, theories of popular sovereignty in which the principal concern is whether the power exercised by rulers is legitimate, in the sense of authorized by popular consent. 
Because of this focus, democratic theory often has little to say about how principles of popular sovereignty are operationalized. Consistent with the idea that the will of the popular sovereign must be formed freely, theories of democracy tend to assume a wide range of acceptable structural choices, and a correspondingly wide range of discretion among polities to choose a form of operationalization that best suits their goals and habits. No theory of democracy, for example, is so fine-grained at the operational level as either to prescribe or to prohibit very substantial yet commonplace variations in the format of democratic self-rule such as parliamentary or presidential systems, first-past-the-post or proportional electoral methods, short or long terms of office, closed or open party lists, and so forth; all such mechanisms are capable of satisfying the main requirement of democratic legitimacy. Insofar as democratic theory is concerned, the key criterion is thus popular sovereignty, not any particular instantiation of it.

A second reason why democratic theories typically offer little guidance at the operational level, particularly as relevant to the structure of candidate nominating systems, is their historic inattention to the role of political parties. More than 70 years ago, the great twentieth-century political scientist Elmer Schattschneider called parties "the orphans of political philosophy," 43 and his description remains apt: "the current literatures on political parties and normative democratic theory continue to develop to an extraordinary degree in mutual isolation .... [M]odern democratic theory is noticeably silent on the question whether political parties have a legitimate place and function in a democracy." 44

Indeed, political parties pose a singular challenge to democratic theory. Parties function as intermediate institutions which, though perhaps pragmatically necessary ${ }^{45}$ stand between the people and their elected representatives, thereby complicating the fulfillment of the principal condition of democratic legitimacy - that rulers must rule subject to some democratically meaningful form of popular consent. Over time, parties have come to exercise an important function in democratic practice by organizing an otherwise chaotic public sphere, filled with differing political views, into an intellectually coherent environment of ideologically competing partisan positions. ${ }^{46}$ The party, in

43 E. E. Schattschneider, Party Government 10 (1942).

44 Ingrid van Biezen \& Michael Saward, Democratic Theorists and Party Scholars: Why They Don't Talk to Each Other, and Why They Should, 6 PersP. ON POL. 21, 22 (2008).

45 Schattschneider famously went so far as to declare that "the political parties created democracy and that modern democracy is unthinkable save in terms of the parties." Schattschneider, supra note 43 , at 1.

${ }^{6}$ Theorists as disparate as Downs and Rosenblum agree on this point. See Downs, supra note 40, at 25-26; Nancy L. Rosenblum, On the Side of the Angels: An Appreciation of Parties and Partisanship 353-56 (2008). 
other words, "coordinates the beliefs and intentions of activists [and] articulates a collective will."47

Democratic legitimacy requires that the popular will dictate the choice of rulers. Parties, however, by definition comprise only a portion of the electorate. If parties "assist" the electorate in formulating its will by defining the universe of options before the popular will is authoritatively formed, then it is not entirely clear that an expression of the popular will formed after parties have done their work is democratically equivalent to the formation of such a will in the absence of party intermediation. To put the matter differently, the role of parties in actively constructing the democratic will lays bare the hard truth, not always acknowledged by democratic theorists, that a democratic will is not an antecedently existing object to be discovered through the application of electoral procedures, but is rather an artifact of those procedures-such a will, in other words, is in large part constructed by the very procedures used to determine it. ${ }^{4}$

\section{Infeasibility of Selecting on the Necessary Criteria}

Finally, even where democratic theory is capable of producing concrete institutional prescriptions, it is often far from clear that nominating institutions can be designed to select candidates on the criteria demanded by the theory. Suppose, for instance, that Americans were to choose on normative grounds to accept guidance in their practice of democracy from some kind of theory of deliberative democracy. The ideal president, in that case, would presumably need to be not only a skilled, patient, and respectful deliberator him- or herself, but also someone capable of facilitating and leading normatively desirable deliberation among different groups, including cabinet officials, members of Congress, interest groups, and the general public.

Fair enough, but how might a nominating system be designed to select candidates on these qualities? One way, as we have seen, is to place a thumb on the scale by careful construction of the selectorate. Given the commitments of deliberative theories of democracy, an appropriate selectorate might thus be comprised of individuals who (1) value the skills of a good deliberative leader and (2) will be more responsive to appeals from potential candidates

47 Jonathan White \& Lea Ypi, The Meaning of Partisanship 85 (2016). In some societies this role has been formally acknowledged: the German Basic Law, for example, provides that parties "participate in the formation of the political will of the people." Const. of Germany, art. 22(1). To similar effect, see Const. of Switzerland, art. 137; Const. of Spain, art. 6.

$4^{8}$ S. I. Benn \& R. S. Peters, Principles of Political Thought 397-99 (1959). 
who display those qualities than to appeals from candidates with other kinds of skills and virtues.

So far, so good. But of whom, then, would the selectorate actually be comprised? How do we identify individuals qualified to serve? Would they require specific kinds of experience or training? Certainly, the selectorate would likely have to be a small and exclusive group; the general public is not known for its great love and respect for genuinely deliberative politics, ${ }^{49}$ particularly in the current era of partisan polarization. Similar problems arise under any of the various theories of democracy now in circulation. Suppose a collective commitment to a theory of protective democracy. To which rights and liberties would a qualified candidate have to be committed, and who decides? How would qualified members of a selectorate be identified, and by whom?

The problem quickly begins to swallow its own tail. Some theories of democracy, most notably democratic minimalism and associated aggregative theories, neither expect nor demand broad public participation during the nomination phase; such theories are satisfied by mass popular choice among whatever set of options may happen to be presented to a passive electorate..$^{\circ}$ Other theories, especially developmental and deliberative ones, often express a robust preference for wider public involvement at every stage of the process. ${ }^{1}$ Thus, the theories that in principle require the greatest public participation at the nominating phase require in practice the most specific and exclusive selectorates, whereas the theories most readily amenable to practical implementation impose no particular requirements on nominating procedures.

Given the challenges associated with taking useful, concrete guidance from democratic theory in the design of nominating procedures, I turn to two other possible methods for guiding presidential nominations along desirable pathways: threshold qualifications and citizen ethos.

49 Elizabeth Theiss-Morse \& John R. Hibbing, Stealth Democracy (2002); James A. Gardner, What Are Campaigns For? The Role of Persuasion in Electoral Law and Politics (2009).

50 Schumpeter, supra note 39, at 260; Schattschneider, supra note 43, at 53-64; Downs, supra note 40, at 36-38, 220-37; Thomas E. Mann, Is This Any Way to Pick a President? Lessons from 2008, in Reforming the Presidential Nomination Process, supra note 24, at 168 .

$5^{1}$ E.g., Fabio Wolkenstein, A Deliberative Model of Intra-Party Democracy, 24 J. PoL. PHIL. 297 (2016); Miguel Pérez-Moneo, La selección de candidatos electorales en los PARTIDOS (2012); Susan E. Scarrow et al., From Social Integration to Electoral Contestation: The Changing Distribution of Power within Political Parties, in Parties without Partisans: Political Change in Advanced Industrial Democracies 130 (Russell J. Dalton \& Martin P. Wattenberg eds., 2000). 


\section{OTHER MECHANISMS OF PATH DEPENDENCY}

\section{A. Candidate Qualifications}

Another common feature of institutional design capable of influencing the qualities of candidates for office is the use of constitutional qualifications and disqualifications. These mechanisms represent a classic form of constitutional self-restraint; they prevent the polity from doing something it might regret - in this case, electing an unqualified individual. At the federal level, the U.S. Constitution establishes qualifications of age, citizenship, and residency. ${ }^{52}$ State constitutions typically establish the same three qualifications for governor, though some add the requirement that governors be qualified voters, ${ }^{53}$ a provision that subjects candidates for executive office to standard grounds of disqualification applicable to voters, such as disqualification for mental incompetence or felony conviction. In some states, term limit provisions add an additional disqualification for having served some prior period in elected office. ${ }^{54}$ The earliest state constitutions often contained property qualifications as well, but those provisions were gradually relaxed during the Jacksonian era, and are in any case of dubious constitutionality. ${ }^{55}$

These kinds of threshold screening requirements, however, do not in themselves identify qualities that officeholders must possess in order to be able to perform the job competently; there is no intrinsic reason why a foreign-born 34-year-old cannot be as good a president as a native-born $3^{6-}$ year-old. Rather, threshold screening requirements serve as proxies for other qualities on which the polity does place considerable weight-experience and maturity of judgment in the case of age; loyalty to the United States in the case of citizenship; knowledge of local needs and interests in the case of residency; and responsiveness to the electorate in the case of term limits.

The utility of qualification provisions, however, seems debatable. First, as with nominating procedures, the most desirable kinds of screening from the point of view of democratic theory pose serious difficulties of implementation.

52 U.S. Const. art. I, $\mathbb{S}$ 2, cl. 2 (Representatives); art. I, $\mathbb{S}_{3}$, cl. 3 (Senators); art. II, $\mathbb{1}$ 1, cl. 5 (President).

53 E.g., Cal. Const., art. IV, $\$ 2$; Fla. Const. art. III, $\$ 5$.

54 E.g., Cal. Const. art. IV, $\$ 2$; Colo. Const. art. IV, $\$ 1$.

55 See Turner v. Fouche, 396 U.S. 346 (1970) and Chappelle v. Greater Baton Rouge Airport District, 431 U.S. 159 (1977), summarily reversing 329 So. 2 d 801 (La. App. 1976) (both reversing state property qualifications for non-elective offices); Harper v. Virginia Board of Elections, 383 U.S. 663 (1966) (invalidating state property requirement for voting eligibility in the form of a poll tax). 
It is no easier to design a threshold qualification to screen for commitment to individual liberty or aggregative or deliberative prowess than it is to design a nominating procedure to produce the same effect.

Second, threshold qualification provisions demonstrate a rather low regard for voter discernment and self-restraint; they presume that voters are sufficiently likely to be tempted by unqualified candidates to require that the electorate as a whole be affirmatively disabled from acting on those temptations. Even if that presumption is accurate, however, threshold qualifications do nothing to prevent voters from deploying this bad judgment by choosing inexperienced, immature, disloyal, ignorant, or corrupt candidates who clear the constitutional minima. Perhaps the most that might be said for qualification provisions is that they prevent voters from electing the most egregiously unqualified candidates, but even that assumption seems dubious: incompetence seems to be generously distributed in the population, even among native-born, lifelong residents over 35 years of age. If identifying a pool of solid, highly competent candidates is the goal, threshold qualifications perform only minimally useful work.

\section{B. Citizen Ethos}

To name citizen ethos as a procedure for screening presidential candidates is in a sense merely to name the condition of having no screening process at all, or at least no formal one. But the absence of a formal process for screening candidates does not mean that no screening criteria exist; it means only that citizens will base their choices among candidates on internalized, politically consensual criteria, if any exist; or in the absence of consensus, that citizens will apply their own personal views of good leadership. Thus, although formal screening and nominating procedures can influence the nature of the ultimate choice, they are not the only source of influence; citizens, as social beings living in a political community, will also respond to prevailing norms of politics. These norms, moreover, will not necessarily be dictated by democratic theory or by some other, presumptively authoritative source of formal principles of governance. Prevailing norms of political choice are just as likely to have their source in convention or in pragmatic considerations. Perhaps the leading example is the pre-Franklin D. Roosevelt norm of a two-term limit as a check on the private ambition of presidential candidates. The strength of this norm served for more than a century to screen out of the candidate pool individuals who had already served two terms as president, not because formal term limits had been imposed by law, but because the prevailing citizen ethos deterred voters from voting for any candidate who had the effrontery to run for 
a third term. During the period when the two-term norm prevailed, such candidates would have appeared to the electorate to be guilty of an overweening ambition inconsistent with successful continued service.

Because informal political norms supply the foundations of citizen decisionmaking in electoral politics, they are potentially the most important force for guiding the nomination of presidential candidates: only individuals whose qualifications comport with these norms will be plausible candidates for election. The great difficulty with relying on such norms, however, is that they are not easily controlled, or even influenced, by law. On the contrary, originating in what Habermas called the "wild' complex" and "anarchic structure" of civil society, ${ }^{5}$ they are vulnerable to social and political movements generated within civil society largely outside of the formal control of law. Indeed, many now argue that the main problem with politics in the United States-and, increasingly, throughout the world - is the deterioration in civil society of longstanding, previously stable norms of democratic citizenship. ${ }^{57}$

This does not mean that citizen ethos cannot be influenced by adjustments to legal and political institutions - the two undoubtedly shape one another in a dialectic process, so that institutional processes are in principle capable of inducing a kind of civic training. Aristotle, for example, argued that the kind of rotation in office typical of Athenian democracy helped to produce good rulers because the experience of being ruled taught citizens valuable lessons about how to rule well, lessons that they could apply when they later held office. ${ }^{8}$ Much more recently, advocates of instant runoff voting argue persuasively that something as simple as allowing voters to indicate second and third choices on the ballot has altered the norms of political campaigning. When candidates stand to benefit by campaigning for voters' lower-ranked votes, they apparently no longer find it in their interest to campaign negatively by smearing and belittling opponents whom some voters might rank higher. This change in institutional incentives has thus produced more harmonious electoral campaigns in which candidates stress their positive attributes rather than their opponents' negatives so as to avoid alienating a slice of potential support. ${ }^{59}$ Such a change in candidate behavior

56 Habermas, supra note 41 , at 307.

57 See, e.g., Steven Levitsky \& Daniel Ziblatt, How Democracies Die (2018); Jamal Greene, Trump as a Constitutional Failure, 93 IND. L.J. 93 (2018); Symposium, Is Democracy in Decline?, 26 J. Democ. 5 ff. (2015).

$5^{8}$ Aristotle, Politics, bk. III, ch. iv, $\int 14-15,1277 \mathrm{~b}$.

59 See, e.g., Jessie Van Berkel, Ranked-choice Voting Alters Calculus in Minneapolis, St. Paul Races, Minneapolis Star-Tribune, Oct. 7, 2017; FairVote, Campaign Civility, www.fairvote.org/research_rcvcampaigncivility (last visited Aug. 2, 2018). 
might in turn generate more positive and less alienated sentiments among the electorate toward candidates and politicians. In this way, then, welldesigned institutional structures can help "train" citizens to think and behave in desirable ways.

However, the most common form of pressure on citizen ethos and informal norms, at least in today's environment of cheap, easy communication, is ideological. At the moment, tremendous efforts are being made by communicative means, financed by enormous private fortunes, to alter prevailing social attitudes on a host of issues. Citizen ethos is now precisely the site of a titanic partisan battle, and for good reason. In addition, the arrival in power of the Trump Administration may well be providing a strong form of civic training: by normalizing behavior that conflicts radically with previously prevailing civic and democratic norms, the administration may well succeed in demolishing those norms and replacing them with others more congenial to non-democratic practices. Citizen ethos thus may well be by far the most significant battleground, quite possibly the only one that really matters.

\section{CONCLUSIONS}

Complaints about the low quality of presidential candidates are hardly new. One of the most astute nineteenth-century observers of American political institutions, Lord James Bryce, devoted a chapter of his 1893 book to the subject "Why Great Men Are Not Chosen President." In Bryce's view, all American presidents since Jackson, with the exception of Lincoln and Grant, had been "intellectual pigmies beside the real leaders of [their] generation." 60 Today, however, the stakes are much higher; unlike in Bryce's time, the United States is no longer merely one relatively advanced nation among many, but the richest and most powerful nation the world has ever known. The quality of its leadership is of concern not only to Americans, but to everyone on the planet.

The historical record shows that the procedures used for nominating presidential candidates have undergone significant change since the founding, and presumably could change again. The logic of institutional analysis shows that the design of nominating systems can influence strongly the qualities of candidates who successfully clear its screening procedures. Institutional logic also suggests that the current trend in nominations of expanding the selectorate to the point where it converges with the electorate tends to nullify the capacity of the nomination process to channel the choice of nominees along

6o James Bryce, 1 The American Commonwealth 84 (1893). 
any particular axis of decision, no matter how desirable. Instead, convergence of the selectorate and electorate tends to result in a kind of functional delegation of the criteria of choice to self-appointed individuals, groups, and candidates, who may not fully share the collective norms of democratic practice that in the end comprise the most significant and effective constraint on the behavior of participants in the nominating process.

At the end of the day, reform of nomination mechanisms may not be the most effective site in which to invest reform energy. What we may need more than institutional reform is a systematic effort to renew, justify, and strengthen democratic norms, an effort that by definition must take place not in the halls of legislatures or party bureaucracies, but deep in the terrain of civil society. 